\title{
Особливості імунологічної реактивності в дітей із резистентним туберкульозом
}

Білогорцева О.І. ${ }^{1}$, Доценко Я.І. ${ }^{1}$, Панасюкова О.Р. ${ }^{1}$, Мотрич І.В. ${ }^{2}$, Садловська М.А. ${ }^{1}$, Хлибова В.С. ${ }^{3}$

1. ДУ «Національний інститут фтизіатрії і пульмонології ім. Ф.Г. Яновського НАМН України», м. Київ, Україна

2. Регіональне бюро Всесвітньої організації охорони здоров’я, Україна

3. КНП «Кіровоградський обласний фтизіопульмонологічний медичний центр Кіровоградської обласної ради», м. Кропивницький, Україна

Матеріали та методи. 3 метою виявлення особливостей імунологічної реактивності в дітей із локальними формами резистентного туберкульозу були обстежені 30 пацієнтів дитячого відділення Національного інституту фтизіатрії і пульмонології віком 10-16 років із діагнозом туберкульозу 3 множинною лікарською стійкістю (МЛС-ТБ). Аналіз стану імунної системи було проведено з урахуванням відсотка відхилень її показників від меж фізіологічної норми. Робота виконана коштом держбюджету.

Результати. У більшості дітей із МЛС-ТБ уміст лейкоцитів, відсотковий та абсолютний уміст лімфоцитів були в межах вікових норм. При аналізі даних системного імунітету встановлено, що в більшості дітей відсотковий і абсолютний уміст загального пулу Т-лімфоцитів, Т-хелперна, Т-супресорна субпопуляції та їх співвідношення (імунорегуляторний індекс - (PI) були в межах норми. Проте при ретельнішому аналізі було виявлено певні зміни. Зокрема, в 30,0 \% дітей спостерігалося зменшення відсоткового вмісту CD8+-лімфоцитів, IPI був зниженим у 46,7 \%, уміст CD16+-лімфоцитів (відсотковий та абсолютний) також був зниженим у 50,0 та 60,0 \% відповідно. Крім того, спостерігалося зменшення відсоткового (в 53,3 \% дітей) та абсолютного (в 33,3 \% дітей) умісту CD19+-лімфоцитів.

У більшості дітей рівні імуноглобулінів A, M і G були в межах вікових норм, у 40,0 \% дітей спостерігався підвищений рівень імуноглобуліну Е. Рівень протитуберкульозних антитіл був підвищеним лише в 63,3 \% пацієнтів.

У більшості обстежених дітей циркулювальні імунні комплекси (ЦІК) середньої молекулярної маси були в межах контролю (63,3 \%), а ЦІК малої молекулярної маси були знижені (56,6 \%).

При аналізі фагоцитарної ланки імунітету було встановлено, що в більшості обстежених дітей поглинальна активність нейтрофільних гранулоцитів і моноцитів крові (відсоток клітин, спроможних до фагоцитозу та фагоцитарне число) знижені на 43,3-70,0 \%, при цьому на тлі зниженої спроможності нейтрофільних гранулоцитів і моноцитів до фагоцитозу спонтанна продукція активних форм кисню цими клітинами в більшості дітей була в межах фізіологічної вікової норми (73,3-80,0 \%).

Висновки. У більшості дітей із мультирезистентним туберкульозом загальний пул Т-лімфоцитів, їхні імунорегуляторні субпопуляції були в межах вікових норм, але захист організму від чужорідних клітин пригнічений, у значної частини обстежених дітей це супроводжувалося зниженням умісту В-лімфоцитів. Для більшості дітей характерним $\epsilon$ підвищений рівень протитуберкульозних антитіл. Дисфункція фагоцитувальних клітин (нейтрофільних гранулоцитів і моноцитів крові) проявлялася пригніченням їхньої поглинальної здатності. 